\title{
A política de garantia de preços mínimos para produtos da sociobiodiversidade (PGPM-Bio): potencialidades da intervenção estatal para a conservação ambiental em Goiás
}

\author{
The minimum price guarantee policy for socio-biodiversity products (PGPM-Bio): potential of \\ state intervention for environmental conservation in Goiás
}

\author{
Camila Vito Silva de Lima ${ }^{1}$ \\ Hamilton Matos Cardoso Júnior ${ }^{2}$ \\ Divina Aparecida Leonel Lunas ${ }^{3}$
}

\section{Resumo}

Este artigo se propõe a apresentar as potencialidades das espécies extrativas passíveis de subvenção econômica no âmbito da Política de Garantia de Preços Mínimos para os Produtos da Sociobiodiversidade (PGPM-Bio) como instrumento para a conservação do Cerrado presente no estado de Goiás. Dessa forma, o trabalho está dividido em três seções: na primeira seção, há breve revisão histórica dos métodos de modernização agrícola implantados em Goiás a partir de meados do século XX e suas consequências na atualidade; na segunda seção é realizada uma explanação sobre a política em questão e são apresentados os resultados de sua implantação entre 2009 e 2015; na terceira seção é realizada breve discussão sobre o desenvolvimento sustentável e sobre as formas de aproveitamento dos produtos extrativos goianos. A metodologia utilizada refere-se à revisão bibliográfica acerca dos temas discorridos e ao uso de pesquisa documental em dados divulgados pela Companhia Nacional de Abastecimento (Conab) e pelo Instituto Brasileiro de Geografia e Estatística (IBGE). A partir das proposições, conclui-se que a PGPM-Bio pode ser ferramenta eficaz na conservação das áreas protegidas no Cerrado por meio das boas práticas de manejo das plantas nativas, na recuperação de áreas degradadas por meio do reflorestamento e na manutenção da cultura, o que tende a conservar, especialmente, frutos símbolos da culinária goiana. Ainda, infere-se que o sucesso da política em Goiás depende do mapeamento das áreas produtivas, da ampla divulgação da política e da formalização da cadeia produtiva, por meio da consolidação dos mercados para os produtos da sociobiodiversidade.

Palavras-chave: Conservação da Natureza. Subvenção Econômica. Produto Florestal Não Madeireiro.

\footnotetext{
Abstract

This article aims to present the potential of extractive species capable of economic subsidy under the Minimum price guarantee policy for the socio-biodiversity products (PGPM-Bio) as a tool for the conservation of the Cerrado present in Goiás. In this way, the work is divided into three

1 Mestranda do Programa de Pós-graduação em Ciências Sociais e Humanidades no Programa de Mestrado em Territórios e Expressões Culturais no Cerrado (TECCER) - Universidade Estadual de Goiás. E-mail: cvitoslima@gmail.com,

${ }^{2}$ Mestre em Ciências Sociais e Humanidades pelo Programa de Mestrado em Territórios e Expressões Culturais no Cerrado (TECCER) - Universidade Estadual de Goiás. Técnico em Assuntos Educacionais do Instituto Federal do Mato Grosso (IFMT). E-mail: hjuniorgo@ hotmail.com.

3 Doutora em Desenvolvimento Econômico pela Universidade Estadual de Campinas (Unicamp). Professora da Universidade Estadual de Goiás. E-mail: divalunas@gmail.com.
} 
sections: the first section, there is a brief historical review of the methods of agricultural modernization in Goiás from the mid-20th century and its aftermath at present; in the second section, an explanation of the policy in question and are presented the results of your deployment between 2009 and 2015; in the third section, is held brief discussion about sustainable development and on ways to use of extractive products Goiás. The methodology refers to the bibliographical review about the discorridos themes and use of documentary research in data published by the national supply company (CONAB) and by the Brazilian Institute of geography and statistics (IBGE). From the propositions, it is concluded that the PGPM-Bio can be an effective tool in conservation in the Cerrado protected areas through good management practices of native plants, in the recovery of degraded areas through reforestation and the maintenance of culture, saving, especially fruits culinary symbols goiana. Still, infers that the success of the policy in Goiás depends on the mapping of productive areas, the wide dissemination of the policy and the formalization of the production chain, through consolidation of the markets for the products of biodiversity.

Keywords: Conservation of Nature; Economic Subsidy; Non-Timber Forest Product.

\section{Introdução}

A tentativa de promover o desenvolvimento sustentável se configurou em um dos principais discursos a serem alcançados pelas nações a partir das últimas décadas do século XX, cujo tema tem sido debatido em inúmeras conferências tanto globais quanto locais que envolvem, especialmente, países de economia capitalista. Essa preocupação se origina dos modos usuais de produção que, a partir da revolução industrial, passaram a considerar o meio ambiente e seus recursos ou como insumos para a produção de um bem final, e, desse modo, serem subutilizados ou descartados, ou como obstáculo para a expansão do processo produtivo, o que acarreta externalidades, muitas vezes, negativas, que não tinham seus custos sociais mensurados e nem sua devida importância levantada.

A partir das respostas dadas pela própria natureza ao modo de produção intensivamente predatório como, por exemplo, as alterações climáticas dos últimos anos, a sociedade atual tem buscado repensar o modo de produção no qual vivemos. A partir daí, emergiu a ideia de desenvolvimento sustentável, o qual busca viabilizar o crescimento econômico atrelado a soluções criativas que visem conservar os recursos naturais e fomentar o bem-estar social com o uso de investimentos financeiros reduzidos.

Grudem e Asmus (2016) apontam a conservação responsável dos recursos naturais como um dos fatores para a superação da pobreza nas nações. Tal conservação depende, em grande parte, de uma intervenção governamental que seja equilibrada e que tenda ao uso consciente dos fatores naturais como geradores de renda e bem-estar social. Para eles, governos que desejem a contínua melhoria socioeconômica devem evitar intervenções tendenciosas, pois assim como podem existir 
medidas extremamente permissivas que levem à "destruição imprudente do meio ambiente", por outro lado podem ser feitas políticas públicas extremamente restritivas que impeçam o uso sensato dos recursos naturais disponíveis, o que resulta em ineficiência econômica (GRUDEM; ASMUS, 2016, p. 299).

No Brasil, o equilíbrio nas tomadas de decisão e ações públicas são de suma importância, sobretudo num país com dimensões continentais e formado por seis biomas - Amazônia, Caatinga, Cerrado, Mata Atlântica, Pampa e Pantanal - com grande diversidade biológica, com características distintas e populações com práticas e saberes peculiares. Aproveitar de forma racional tamanha riqueza, com o fomento do crescimento econômico e, concomitantemente, a conservação da cultura e do meio ambiente é um desafio que requer, consoante Veiga e Ehlers (2010), a combinação de mecanismos diversos de intervenção pública com vistas a tornar mais vantajosa a escolha de novos negócios que conservem e/ou recuperem a natureza em detrimento àqueles que a degradam.

Os autores exemplificam como solução para esse impasse o financiamento de sistemas agroextrativistas, como a integração lavoura-pecuária-floresta, ou incentivos ao uso do meio rural para satisfazer amenidades da população urbana, como o turismo rural e ecológico. Dessa forma, haveria, ao mesmo tempo, a criação de empregos, a geração de renda e a conservação dos recursos naturais.

Segundo essa perspectiva, Abramovay (2012) apoia a economia verde e convoca as estruturas multilaterais (governo, empresas e sociedade civil) a pensarem para além dela ao apropriar-se de uma vertente pensada pela geógrafa Bertha Becker, que é a da economia do conhecimento da natureza, que consiste na exploração benéfica dos recursos disponíveis na sociobiodiversidade e que objetiva criar "cadeias de valor ligadas a produtos florestais (madeireiros e não madeireiros), mas também a serviços ecossistêmicos, com base nos quais prosperem negócios que beneficiem as populações que vivem em regiões de grande riqueza biológica" (ABRAMOVAY, 2012, p. 84).

Nesse sentido, o Estado brasileiro, baseado na Lei $\mathrm{n}^{\mathrm{o}}$ 8.171, de 17 de janeiro de 1991 (BRASIL, 1991), que dispõe sobre a política agrícola, foi incumbido, além de planejar, regular e fiscalizar a atividade agrícola no Brasil, de criar ações que protejam, conservem e recuperem os recursos naturais e que, também, simultaneamente ou não, viabilizem a produção e a comercialização de produtos quer agropecuários, quer florestais ou pesqueiros, e, ainda, fomentem o associativismo e o cooperativismo. Assim, ao longo dos anos, iniciativas foram adotadas pelo poder público a fim de fortalecer a atividade agrícola em todas as suas instâncias.

Contudo, somente a partir do Plano Nacional de Promoção das Cadeias de Produtos da Sociobiodiversidade (PNPCPS) que a temática da conservação da natureza e da cultura, juntamente 
com a garantia de renda aos seus habitantes, muitas vezes excluídos socialmente por seu baixo poder aquisitivo, foi estruturada. É nesse contexto que a Política de Garantia de Preços Mínimos para Produtos da Sociobiodiversidade (PGPM-Bio) foi criada: a partir do Eixo 7.3 do PNPCPS que aborda a "estruturação e fortalecimento de mercados para os produtos da sociobiodiversidade" (BRASIL, 2009, p. 12).

Destarte, a PGPM-Bio é um tipo de subvenção econômica que visa equalizar os preços de alguns produtos extrativos que sejam comercializados com valores inferiores àqueles estipulados pelo Governo Federal. Os produtos da sociobiodiversidade estão presentes em todo o território nacional e são obtidos diretamente dos variados ecossistemas brasileiros ou a partir de pequenas benfeitorias artesanais, como é o caso da castanha-do-brasil na região Norte e o da erva-mate na região Sul, e necessitam da criação de mercados ou do fortalecimento dos mercados já existentes.

Desde o seu início, a PGPM-Bio não obteve nenhum acesso em Goiás, embora a gama de produtos com cadeia produtiva com base extrativista seja abundante no estado, pois todo o território goiano é recoberto pelo bioma Cerrado, que possui mais de 11 mil espécies vegetais, com boa parte destas endêmicas e aptas ao consumo. A fauna do Cerrado também é riquíssima, com 199 espécies de mamíferos, 837 espécies de aves, 1.200 espécies de peixes, 180 espécies de répteis e 150 espécies de anfíbios. Dos produtos extrativos não madeireiros, os principais, que possuem maior consumo tanto das comunidades tradicionais como das populações urbanas, são o pequi, o buriti, a mangaba, a cagaita, o bacupari, o cajuzinho do Cerrado, o araticum e o baru (BRASIL, 2017).

Assim, na busca por compreender os motivos da inexistência de subvenção econômica aos produtos extrativos goianos até o presente momento, este artigo se propõe a identificar as potencialidades dos produtos florestais não madeireiros presentes do Cerrado através da PGPM-Bio como mecanismo governamental para a conservação desse importante bioma tão devastado pelas práticas agropecuárias predominantes em Goiás.

Para tanto, o artigo está divido em três seções: na primeira, é realizada uma reflexão histórica acerca do modo de produção agrícola implantado desde a segunda metade do século XX em solo goiano e seu atual estágio de consolidação; na segunda seção é apresentada a Política de Garantia de Preços Mínimos para Produtos da Sociobiodiversidade (PGPM-Bio), seu aparato legal, seus objetivos, sua forma de funcionamento e, também, o que fora realizado em nível nacional entre 2009 e 2015; por fim, na última seção, são descritas as possibilidades de subvenção econômica do estado de Goiás, bem como seus possíveis impedimentos. Metodologicamente, para a elaboração deste trabalho foi utilizada a pesquisa teórica, com a revisão bibliográfica de estudos acerca dos temas desenvolvidos ao longo do texto, e a pesquisa documental na legislação pertinente e bancos 
de dados ou informações virtuais da Companhia Nacional de Abastecimento (Conab) e do Instituto Brasileiro de Geografia e Estatística (IBGE).

\section{A modernização e o atual sistema de produção no Cerrado}

De acordo com a Empresa Brasileira de Pesquisa Agropecuária (EMBRAPA, 2005), o bioma Cerrado ocupa aproximadamente 207 milhões de hectares, equivalentes a $24 \%$ do território nacional. Nos últimos cinquenta anos, esse bioma tem sido intensamente apropriado pelo capital agroindustrial pela expansão da pecuária extensiva e pela exploração de seus recursos minerais. Em poucos anos, o Cerrado viu suas bases sociais e econômicas serem intensamente alteradas pelo "aproveitamento" de suas potencialidades.

Em virtude disso, o Cerrado tornou-se uma das principais regiões de produção agroindustrial do Brasil. O processo de incorporação econômica e produtiva desse bioma se intensificou a partir dos anos de 1970. Contudo, as primeiras décadas do século XX já foram marcadas por ações direcionadas às regiões do Cerrado, com intuito de integrá-las e modernizá-las.

A respeito disso, no bojo da política da Marcha para o Oeste, pode-se citar as ações do governo de Getúlio Vargas com a implantação de duas importantes colônias agrícolas no Cerrado: Colônia Nacional de Goiás (1941), em Goiás, e a Colônia Nacional de Dourados (1943), no atual território do estado do Mato Grosso do Sul. Conforme Pessoa (2009), a Colônia Agrícola Nacional de Goiás foi "uma intervenção muito bem calculada, preparando o avanço do capital em uma região em que, uma inserção deste, por conta própria, seria pouco vantajosa” (PESSOA, 2009, p. 190).

Instituições como a Fundação Brasil Central (FBC), atualmente Superintendência de Desenvolvimento Econômico do Centro-Oeste (Sudeco), muito contribuiu para a integração do Cerrado à economia nacional. De acordo com Maciel (2012), a FBC foi de extrema importância para a incorporação desse bioma à economia do Brasil, pois atuou na implantação de rotas de comunicação, criação de cidades e de postos avançados na região Centro-Oeste em sua principal expedição: Roncador-Xingu iniciada em 1943.

Consoante a Almeida, Vieira Júnior e Ramos (2006), a criação de duas grandes $\operatorname{cidades}^{4}$ na região também contribui para a integração e ampliação da infraestrutura sobre o Cerrado. A inauguração de Goiânia, anterior à Marcha para ao Oeste em 1937, representou forte estímulo migratório para a região. No entanto, foi a construção de Brasília, na década de 1960, que intensificou o processo de migração para a região e viabilizou a integração do Cerrado, através da

\footnotetext{
${ }^{4}$ Atualmente, Goiânia e Brasília são as duas grandes metrópoles do Cerrado, possuindo, respectivamente, 1.302 .001 e
} 2.570.160 habitantes (IBGE, 2017). 
implantação de uma importante malha viária que ligou o Centro-Oeste aos principais centros econômicos do Brasil.

Já na segunda metade do século XX, importantes políticas desenvolvimentistas foram direcionadas às áreas do Cerrado. Programas como o II Plano Nacional de Desenvolvimento (II PND) e o Programa de Desenvolvimento dos Cerrados (POLOCENTRO) ${ }^{5}$, este último fruto de um plano de ação do primeiro, contribuíram para que a estrutura produtiva da região fosse alterada, o que culminou com sua incorporação ao modo de produção capitalista. Para Silva (2000), os investimentos realizados por esses programas tiveram o papel de dar apoio ao processo de ocupação e modificação na estrutura produtiva do Cerrado já em curso.

Nesse processo de modernização do Cerrado, implantado pelas referidas ações estatais, três elementos foram importantes para a inclusão desse bioma no circuito espacial da produção capitalista no Brasil, quais sejam: os recursos naturais (as sintropias); o preço da terra; e as inovações tecnológicas.

De acordo com Shiki (1997), o principal elemento que viabilizou a expansão do modo de produção capitalista sobre o Cerrado foram as sintropias. Para Shiki (1997), as sintropias são os recursos naturais de uma determinada região, como os depósitos minerais, as matas, os rios e os solos cultiváveis. Essas sintropias serviram de base para a expansão do sistema de produção capitalista por subsidiarem com insumos, principalmente, a expansão das lavouras intensivas de soja e milho.

O fator terra, como nos aponta Rezende (2002), também desempenhou importância na atração de agroindústrias para região. Grande parte do solo do Cerrado é considerado de baixa qualidade para a grande agricultura. Por esse motivo, como nos aponta o autor, a terra desse bioma possuía preço inferior à terra de outras regiões (Sul e Sudeste), o que compensou a distância dessa região com relação aos principais centros de consumo e exportação.

Atrelado a esse fator, ainda de acordo com o autor, as inovações tecnológicas, a técnica e a ciência viabilizaram a alteração da terra considerada improdutiva em terra altamente produtiva. Através do uso de insumos químicos (fertilizantes, uso do calcário agrícola, potássio etc.) as terras consideradas de baixa qualidade foram convertidas em terras de qualidade superior. A respeito disso, Rezende (2002) afirma:

Assim, a abundância de terras de qualidade inferior ("terra de segunda") traduziase, mediante a "construção do solo", em abundância de terra de qualidade superior ("terra de primeira"). Embora requerendo tempo para se materializar, esse aumento

\footnotetext{
${ }^{5}$ Consoante Scheibe (1985), o POLOCENTRO foi o principal programa para o desenvolvimento do Cerrado do II PND. Ele viabilizou a aplicação de recursos financeiros na ordem de US\$ 248 milhões entre as décadas de 1970 e 1980.
} 
da quantidade de terra de primeira não poderia senão fazer cair o preço relativo no plano nacional, como consequente aumento da competividade agrícola nacional. (REZENDE, 2002, p. 9).

Do mesmo modo, podemos citar o uso de máquinas modernas na plantação, manutenção e colheita das lavouras, bem como a técnica de irrigação das plantações como de importância para a integração do Cerrado ao modo de produção capitalista. Consequentemente, têm-se a modificação das bases produtivas consideradas tradicionais e a intensificação do fator produtivo tecnologia na região.

Pode-se afirmar que a expansão do modo de produção capitalista sobre o Cerrado, em especial no estado de Goiás, se deu de forma efetiva e resultou em um novo modelo de produção, baseado principalmente na produção monopolista de grãos (soja e milho) e na pecuária extensiva.

Shiki (1997) nos afirma que o atual sistema de produção no Cerrado está amparado no sistema agroalimentar. A indústria agroalimentar na região, ainda de acordo com o autor, é caracterizada por indústrias a montante e a jusante. As indústrias a montante integram o rol das que beneficiam a matéria-prima, principalmente recursos minerais, a exemplo do calcário agrícola, que subsidiaram a monocultura intensiva de grãos. Por outro lado, as indústrias a jusante são compostas pelas que processam a matéria-prima agrícola em produtos consumíveis.

Contudo, a modernização dos processos produtivos que se deu no Cerrado foi excludente e seletiva. As políticas em muito privilegiaram grandes grupos econômicos agroindustriais, principalmente os estrangeiros, e os grandes proprietários de terras em detrimento do pequeno produtor ou das comunidades tradicionais.

Além do caráter conservador da modernização, as transformações ocorridas no Cerrado também têm contribuído para o agravamento da questão ecológica nesse bioma. De acordo com Graziano Neto (1985), os principais problemas trazidos pela modernização agrícola voltada à exploração predatória do Cerrado são: a exaustão do solo devido a seu intenso uso pelas monoculturas intensivas e pela pecuária extensiva; o descontrole de pragas e doenças; a perda da qualidade biológica dos alimentos; a contaminação dos alimentos e do homem por conta do uso de defensivos agrícolas; e a poluição e a destruição da fauna e da flora.

Diante desse contexto, torna-se emergente o surgimento de um novo paradigma de produção no Cerrado que possa dar conta do aproveitamento de suas potencialidades de forma a proteger seu ambiente natural, gerar e criar rendas alternativas às comunidades tradicionais e aos pequenos produtores do campo. Nesse sentido, nos próximos tópicos discutiremos o papel da Política de Garantia do Preço Mínimo para a Sociobiodiversidade (PGPM-Bio) como política para a conservação socioambiental e inclusão social no Cerrado goiano. 


\section{A Política de Garantia de Preços Mínimos para os Produtos da Sociobiodiversidade e sua atuação nacional}

A preocupação recorrente em estabelecer novas formas de aproveitamento dos produtos da biodiversidade, em contrapartida aos danos causados pelo exaustivo uso da terra, tem refletido na criação de mecanismos que precifiquem os custos ou benefícios gerados pelo uso dos recursos naturais. Tais externalidades são denominadas, de acordo com Relatório-Síntese da Avaliação Ecossistêmica do Milênio, como serviços ambientais e podem ser classificados em: serviços de provisão (alimentos e água), serviços reguladores (clima, inundações), serviços culturais (lazer, paisagem) ou serviços de suporte (formação do solo, fotossíntese). (MEA, 2005, p. 7).

A partir dessa concepção, o Pagamento por Serviços Ambientais (PSA) tem sido a ferramenta de curto prazo mais adotada pelos governos no sentido de aplacar os danos causados pelos modos de produção tradicionais e que ocasionou, assim, a criação de mercados para os serviços ambientais como, por exemplo, a venda de créditos de carbono. Shiki et al. (2016) destacam a importância desses métodos ao afirmar que:

[...] os serviços ambientais oferecidos pelos ecossistemas têm valor intrínseco incomensurável pelo fato de ser simplesmente o suporte da vida no planeta e se tornam passíveis de comoditização na mesma medida em que a degradação e a depleção dos ecossistemas gerem disfunções ecossistêmicas que afetem a economia e o bem-estar humano. (SHIKI et al., 2016, p. 336).

A "comoditização" desses serviços se traduz, portanto, na abertura de nichos de mercado, como a indústria de medicamentos naturais, bem como a expansão dos mercados já existentes, como as indústrias do ramo alimentício. No Brasil, uma das medidas criadas pela intervenção estatal para viabilizar o comércio dos produtos de tão variada biodiversidade foi a implantação de subvenções econômicas para alguns produtos extrativos que já possuam, ao menos, mercados informais.

As operações de subvenção econômica por meio da garantia de preços mínimos foram estabelecidas através do Decreto-Lei no 79, de 19 de dezembro de 1966 (BRASIL, 1966), com o propósito de assegurar aos produtores rurais, organizados ou não em cooperativas, a remuneração básica por sua atividade através da compra de seus produtos pelo valor mínimo fixado ou por meio da concessão de financiamentos, com recursos do Tesouro Nacional, para todas as etapas da produção, inclusive o transporte do bem comercializado.

Posteriormente, a Lei $\mathrm{n}^{\circ}$ 8.427, de 27 de maio de 1992 (BRASIL, 1992), acrescentou, ao aparato da subvenção econômica, a equalização das taxas de juros das operações de crédito rural e a 
equalização dos preços de produtos agropecuários ou extrativos. Esta última tem sido o objeto da Política de Garantia de Preços Mínimos para os Produtos da Sociobiodiversidade (PGPM-Bio), conforme os termos do artigo $2^{\circ}$, inciso IV, da referida lei, em redação dada pela Lei $n^{\circ} 11.775$, de 17 de setembro de 2008, que afirma:

Art. $2^{\circ}$ A equalização de preços consistirá em subvenção, independentemente de vinculação a contratos de crédito rural, nas operações amparadas pela política de garantia de preços mínimos, de que trata o Decreto-Lei $\mathrm{n}^{\circ} 79$, de 19 de dezembro de 1966, equivalente:

[...]

IV - no máximo, à diferença entre o preço mínimo e o valor de venda de produtos extrativos produzidos por agricultores familiares enquadrados nos termos do art. $3^{\circ}$ da Lei $\mathrm{n}^{\circ}$ 11.326, de 24 de julho de 2006, ou por suas cooperativas e associações, limitada às dotações orçamentárias e aos critérios definidos em regulamento. (BRASIL, 2008).

Assim, a equivalência dos preços no âmbito da PGPM-Bio acontece no pagamento de um bônus financeiro ao beneficiário da política que comprove a venda formal do produto passível de subvenção. Tal bônus é o resultado da multiplicação entre a diferença do preço comercializado em relação ao preço mínimo estipulado pelo governo e a quantidade vendida do bem.

Além do enfoque na geração de renda, a PGPM-Bio visa, ainda, à proteção e à conservação dos recursos naturais restritos a cada um dos biomas brasileiros. Os ecossistemas neles presentes são capazes de influenciar comunidades e, dessa forma, gerar culturas particulares que, se somadas ao ambiente que as circundam, dão origem à sociobiodiversidade de determinado local.

O Plano Nacional de Promoção das Cadeias de Produtos da Sociobiodiversidade (PNPCPS) explica que a sociobiodiversidade é um "conceito que expressa a inter-relação entre a diversidade biológica e a diversidade de sistemas socioculturais" (BRASIL, 2009, p. 6). Dessa forma, as medidas para a conservação ambiental incorporaram, também, práticas e saberes de indivíduos que mantêm uma interdependência tanto econômica quanto cultural dos elementos da natureza que os rodeiam.

Tais indivíduos podem ser agricultores familiares, silvicultores, aquicultores, extrativistas, agroextrativistas, pescadores artesanais, povos indígenas e integrantes de comunidades remanescentes de quilombos rurais e de povos tradicionais, como é o caso das quebradeiras de coco babaçu no estado do Maranhão, e devem, obrigatoriamente, estar em conformidade com os requisitos do artigo $3^{\circ}$ da Lei $n^{\circ} 11.326$, de 24 de julho de 2006 (BRASIL, 2006), além de possuir a Declaração de Aptidão ao Pronaf (DAP). O acesso à política pode ocorrer de maneira individualizada ou através de associações ou cooperativas legalmente constituídas que representem os beneficiários anteriormente especificados (CONAB, 2015, p. 1). 
Os produtos da sociobiodiversidade são aqueles que, além de originarem-se na natureza local, devem estar envolvidos em cadeias produtivas que propiciem a manutenção dos valores culturais de quem os coleta. É a partir dessa lógica que os produtos amparados pela PGPM-Bio estão distribuídos regionalmente, conforme a Figura 1, embora o pagamento das subvenções ocorra em esfera estadual.

Alguns produtos, contudo, não estão disponíveis para toda a região, mas unicamente em alguns estados. Na região Centro-Oeste, o babaçu, a borracha natural extrativa e a castanha-dobrasil são subvencionados apenas no estado do Mato Grosso. Na região Nordeste, a subvenção da piaçava só pode ocorrer no estado da Bahia. Na região Norte, o baru somente pode ser subvencionado no estado do Tocantins que, por sua vez, não pode receber a subvenção da borracha natural extrativa. Ainda, a subvenção do cacau extrativo deve acontecer exclusivamente no estado do Amazonas. Por fim, na região Sudeste somente é permitida as subvenções do baru e do pinhão nos estados de Minas Gerais e São Paulo.

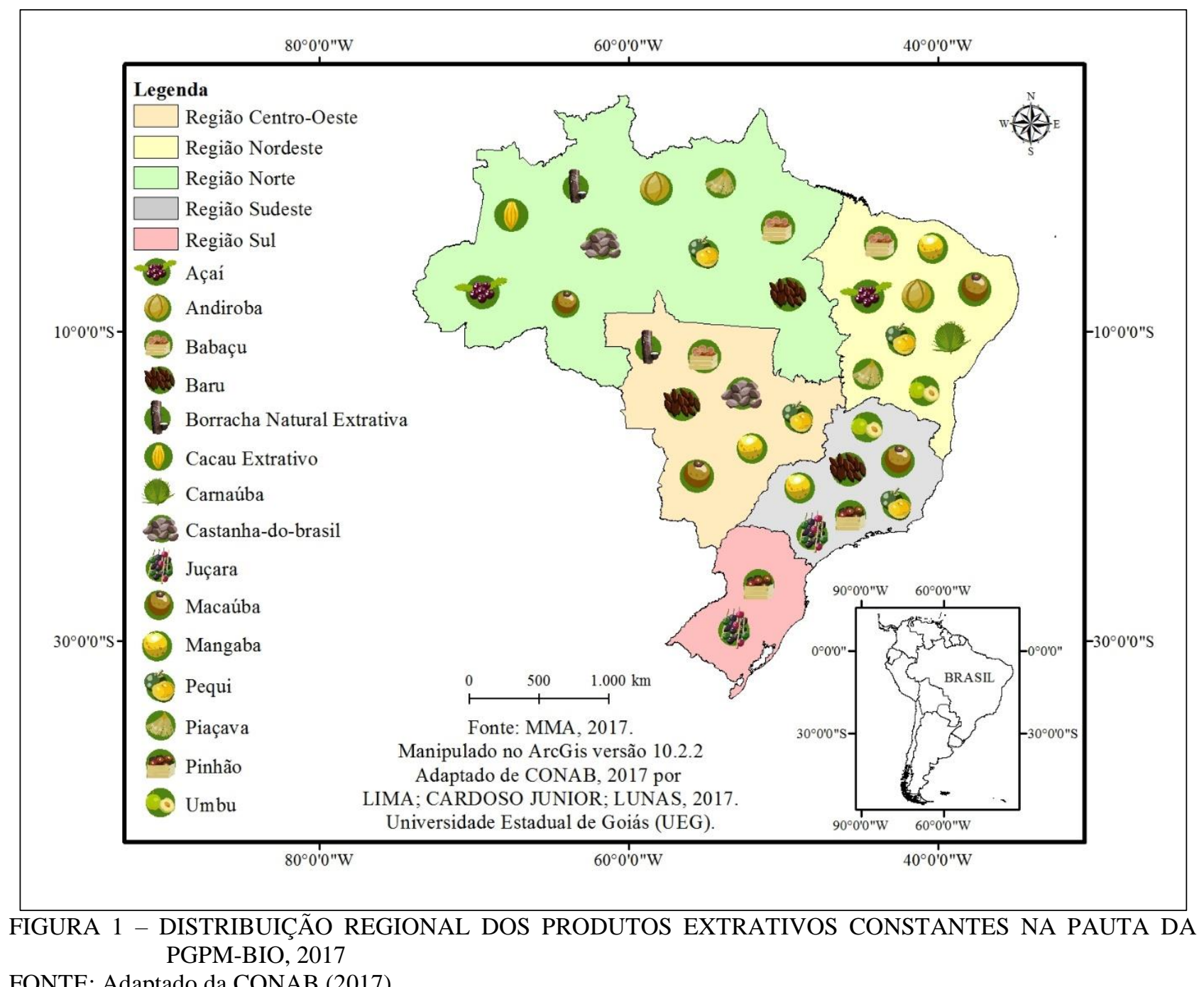

FONTE: Adaptado da CONAB (2017). 
Os produtos passíveis de subvenção possuem formas de apresentação e preços mínimos específicos, como observado na Tabela 1. Os preços mínimos são estabelecidos a partir de pesquisas realizadas em localidades com maior incidência do produto com a finalidade de mensurar os custos médios de produção para cada safra.

Ainda, cada produto subvencionado possui limite máximo para pagamento da subvenção, que não pode ser ultrapassado quando da vigência da safra. Entretanto, é permitido o acesso à subvenção de vários produtos cumulativamente.

A gestão governamental da PGPM-Bio é realizada, conjuntamente, pelos ministérios da Fazenda (MF), do Planejamento, Orçamento e Gestão (Mpog), da Agricultura, Pecuária e Abastecimento (Mapa), do Meio Ambiente (MMA) e do Desenvolvimento Agrário (MDA). No entanto, a execução da PGPM-Bio é feita, exclusivamente, pela Companhia Nacional de Abastecimento (Conab), empresa pública vinculada ao Ministério da Agricultura, Pecuária e Abastecimento e que está presente em todas as Unidades da Federação.

TABELA 1 - PRODUTO, FORMAS DE APRESENTAÇÃO, PREÇO MÍNIMO E LIMITE DE SUBVENÇÃO DA PGPM-BIO PARA A SAFRA 2016/2017

\begin{tabular}{|c|c|c|c|c|}
\hline Produto & Nome científico & $\begin{array}{c}\text { Forma de } \\
\text { apresentação }\end{array}$ & $\begin{array}{l}\text { Preços mínimos } \\
\text { (R\$/kg) }\end{array}$ & $\begin{array}{c}\text { Limites de } \\
\text { subvenção } \\
(\mathrm{R} \$ / \mathrm{kg})\end{array}$ \\
\hline Açaí & Euterpe oleracea & Fruto & 1,29 & $1.000,00$ \\
\hline Andiroba & Carapa guianensis & Amêndoa & 1,43 & $2.000,00$ \\
\hline Babaçu & Attalea speciosa & Amêndoa & 2,87 & $3.000,00$ \\
\hline Baru & Dipteryx alata & Amêndoa & 13,22 & $1.000,00$ \\
\hline Borracha Natural Extrativa & Hevea brasiliensis & Cernambi & 5,42 & $3.000,00$ \\
\hline Cacau Extrativo & Theobroma cacao & Amêndoa & 6,22 & $2.000,00$ \\
\hline Carnaúba & Copernicia prunifera & Cera (bruta gorda) & 13,66 & $2.000,00$ \\
\hline Carnaúba & Copernicia prunifera & Pó Cerífero (tipo B) & 8,30 & $1.000,00$ \\
\hline Castanha-do-brasil & Bertholletia excelsa & Com casca & 1,27 & $2.000,00$ \\
\hline Juçara & Euterpe edulis & Fruto & 2,08 & $2.000,00$ \\
\hline Macaúba & Acrocomia aculeata & Fruto & 0,55 & $3.000,00$ \\
\hline Mangaba & Hancornia speciosa & Fruto & $2,29^{1}$ & $2.000,00$ \\
\hline Mangaba & Hancornia speciosa & Fruto & $1,63^{2}$ & $2.000,00$ \\
\hline Pequi & Caryocar brasiliense & Fruto & 0,56 & $2.000,00$ \\
\hline Piaçava & Attalea funifera & Fibra & 1,91 & $3.000,00$ \\
\hline Pinhão & Araucaria angustifolia & Semente & 2,64 & $2.000,00$ \\
\hline Umbu & Phytolacca dioica & Fruto & 0,62 & $2.000,00$ \\
\hline
\end{tabular}

FONTE: Adaptado de BRASIL (2016).

NOTA: ${ }^{1}$ Preço praticado nas subvenções do produto que ocorram na região Nordeste. ${ }^{2}$ Preço praticado nas subvenções do produto que ocorram nas regiões Centro-Oeste e Sudeste. 
Desde 2009, início da política, até o ano de 2015, os pagamentos acumulados das subvenções ultrapassaram a quantia de 28 milhões de reais. A Figura 2 aponta que os valores pagos apresentaram oscilações, mas com tendência de crescimento moderado ao longo dos anos. Entre 2011 e 2013, houve a maior elevação do período: um incremento de quase $270 \%$ nas operações de pagamento, com o maior patamar no volume de subvenções ocorrido no ano de 2013. Nos anos seguintes, após uma variação negativa de 30,3\%, o pagamento das subvenções se manteve próximo aos 5 milhões de reais.

As variações nos somatórios de pagamento das subvenções podem estar ligadas ao Ciclo de Vida do Produto Extrativo (CVPE). De acordo com Homma (2012), os produtos extrativos possuem um ciclo de vida permeado por três fases: expansão, estabilização e declínio.

$\mathrm{Na}$ etapa expansiva, ocorre o crescimento da demanda pelo bem e sua extração para fins comerciais se eleva, com o efeito da existência de grande quantidade do produto no mercado. Posteriormente, na etapa de estabilização, a capacidade máxima de oferta do produto é alcançada em virtude do expressivo estoque produzido na primeira fase e, também, pela redução da produtividade dos recursos naturais e da mão de obra utilizada na extração, o que conduz à elevação dos custos.

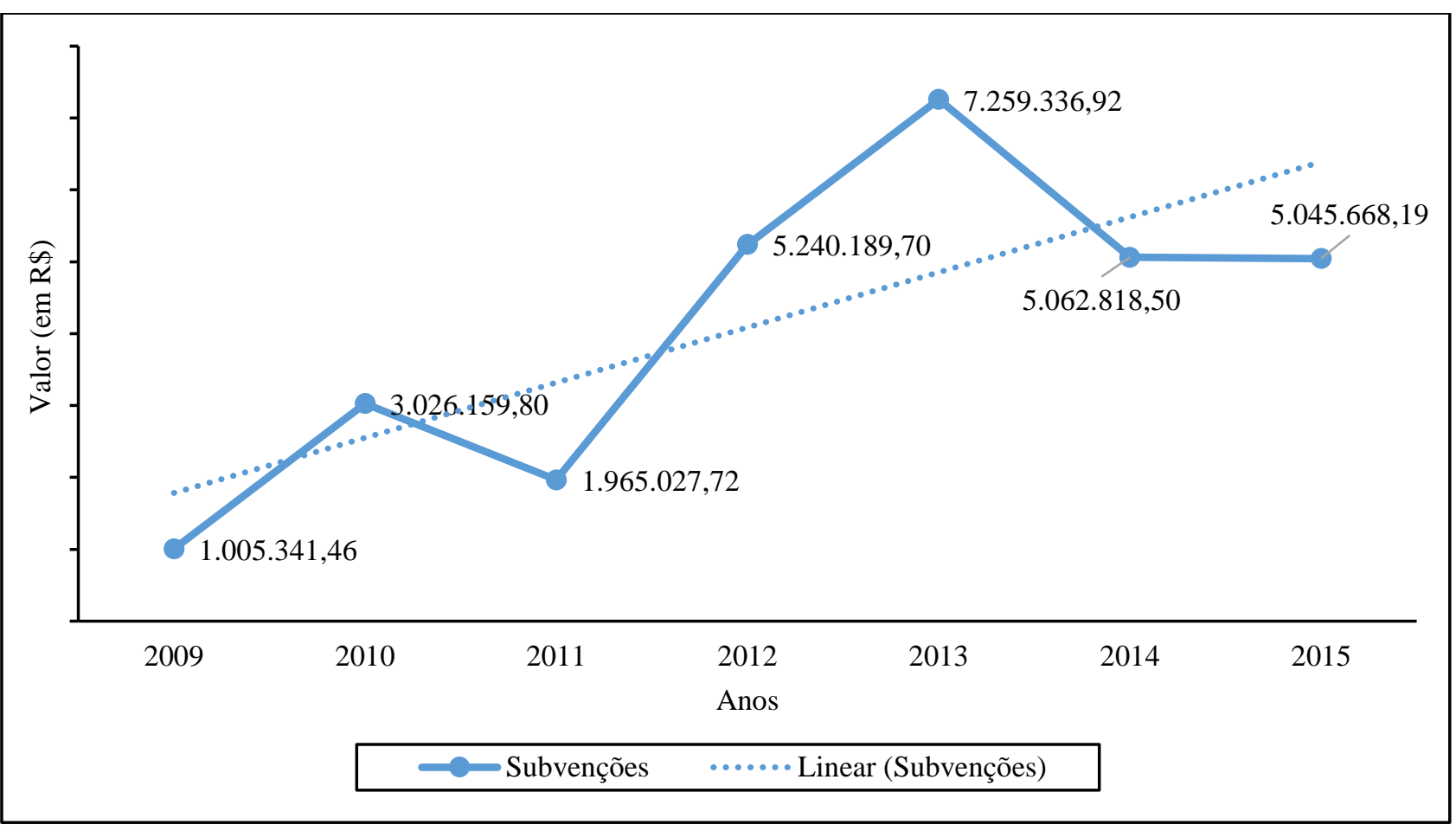

FIGURA 2 - EVOLUÇÃO DOS PAGAMENTOS DAS SUBVENÇÕES REALIZADAS NO ÂMBITO DA PGPMBIO NO BRASIL, 2009-2015

FONTE: Adaptado de CONAB (2017). 
O ciclo extrativo se encerra com o esgotamento das fontes e, assim, necessário se faz buscar novas áreas ou iniciar o cultivo do produto comercializado, que é possibilitado por sua domesticação economicamente viável. O autor acrescenta que "a expansão da fronteira agrícola, a criação de alternativas econômicas, o aumento da densidade demográfica, o processo de degradação, o aparecimento de produtos substitutos" também são fatores que influenciam o declínio da atividade. (HOMMA, 2012, p. 168).

Outro fator que interfere na execução da política é a existência ou não de mercados formais para os produtos subvencionados, uma vez que a comercialização deve ser comprovada mediante a emissão de nota fiscal. A Figura 3 revela uma concentração das operações da PGPM-Bio: a maior parcela das subvenções realizadas entre 2009 e 2015 ocorreu em estados das regiões Nordeste e Norte, e cerca de $75 \%$ delas se deu no bioma amazônico, locais em que o mercado para os produtos extrativos é mais pujante e está em estágio mais avançado de formalização.

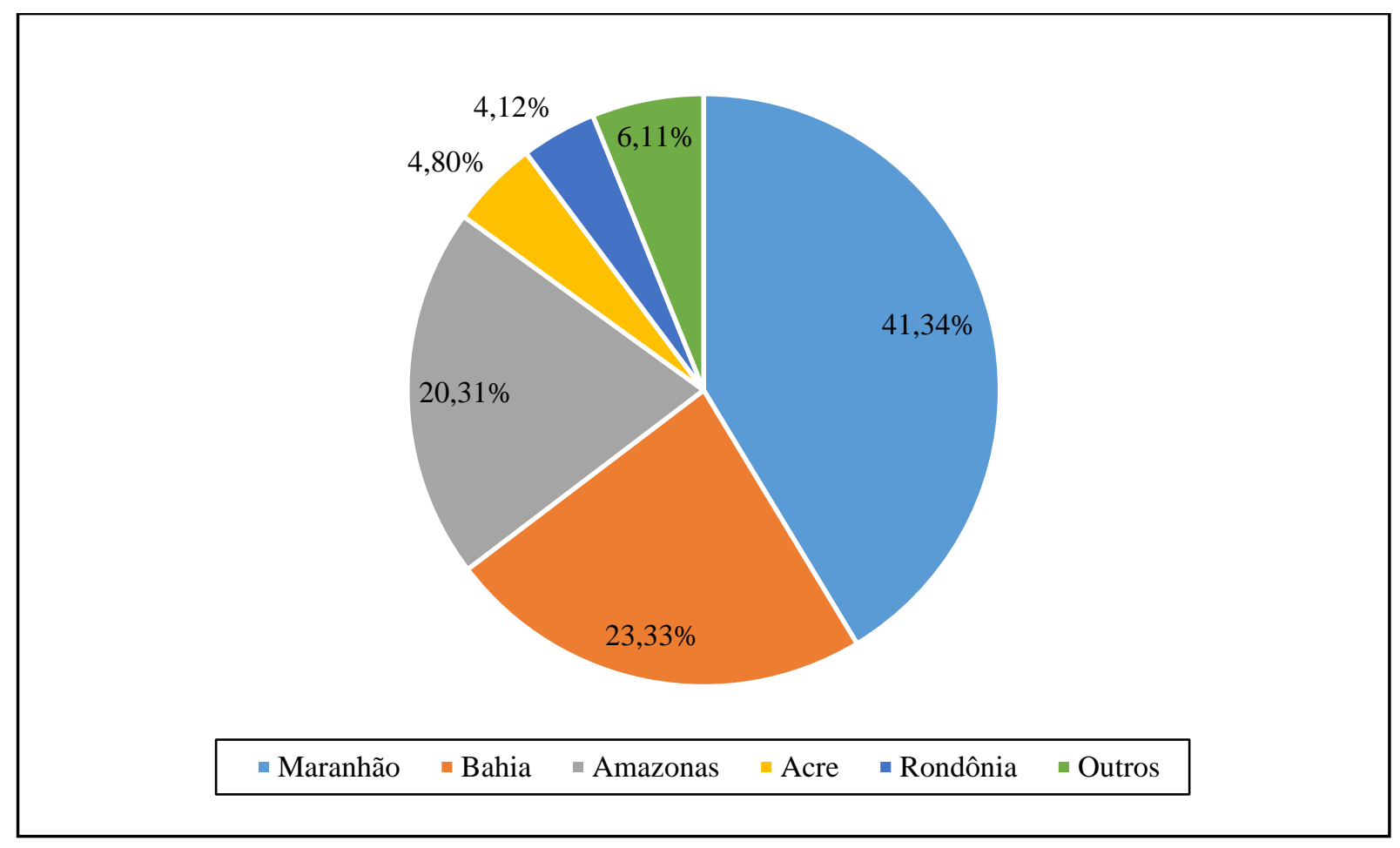

FIGURA 3 - DISTRIBUIÇÃO DOS PAGAMENTOS DAS SUBVENÇÕES DA PGPM-BIO NO BRASIL, 2009-201 FONTE: Adaptado de CONAB (2017).

Calderon (2013) afirma que, em 2011, do valor total de produtos madeireiros não florestais produzidos e comercializados no Brasil, 57\% deles eram provenientes da Amazônia. Ao analisar 28 espécies, o autor comprovou que $46 \%$ delas tinham a produção altamente concentrada naquele bioma: açaí (99,9\%), babaçu (94,2\%), castanha-do-brasil (100\%), palmito $(99,9 \%)$, hevea em forma 
de látex coagulado (99,9\%), copaíba em forma de óleo (100\%), jaborandi (100\%), cumaru (100\%), hevea em forma de látex líquido (100\%), ipecacuanha ou poaia (100\%), sorva (100\%), buriti (88\%).

Nas operações de subvenção não é diferente: dos cinco estados que mais obtiveram pagamentos de subvenção, quatro deles estão na Amazônia e a maioria dos produtos subvencionados foram elencados por Calderon (2013). São eles: no Maranhão, o babaçu; no Amazonas, a borracha, a castanha-do-brasil, a piaçava, o cacau extrativo e o açaí; no Acre, a borracha e a castanha-do-brasil; e, também, em Rondônia, a borracha e a castanha-do-brasil.

Mesmo com as subvenções localizadas, a PGPM-Bio esteve longe de alcançar seus objetivos: entre 2009 e 2015 alguns produtos nunca foram subvencionados, como é o caso do baru, da carnaúba (em suas duas formas de apresentação), da juçara e do umbu, e o potencial de pagamento das subvenções não fora completamente explorado. A esse respeito, a Figura 4 mostra os percentuais utilizados nos pagamentos das subvenções em relação ao valor de recursos destinados anualmente por meio de portarias interministeriais.

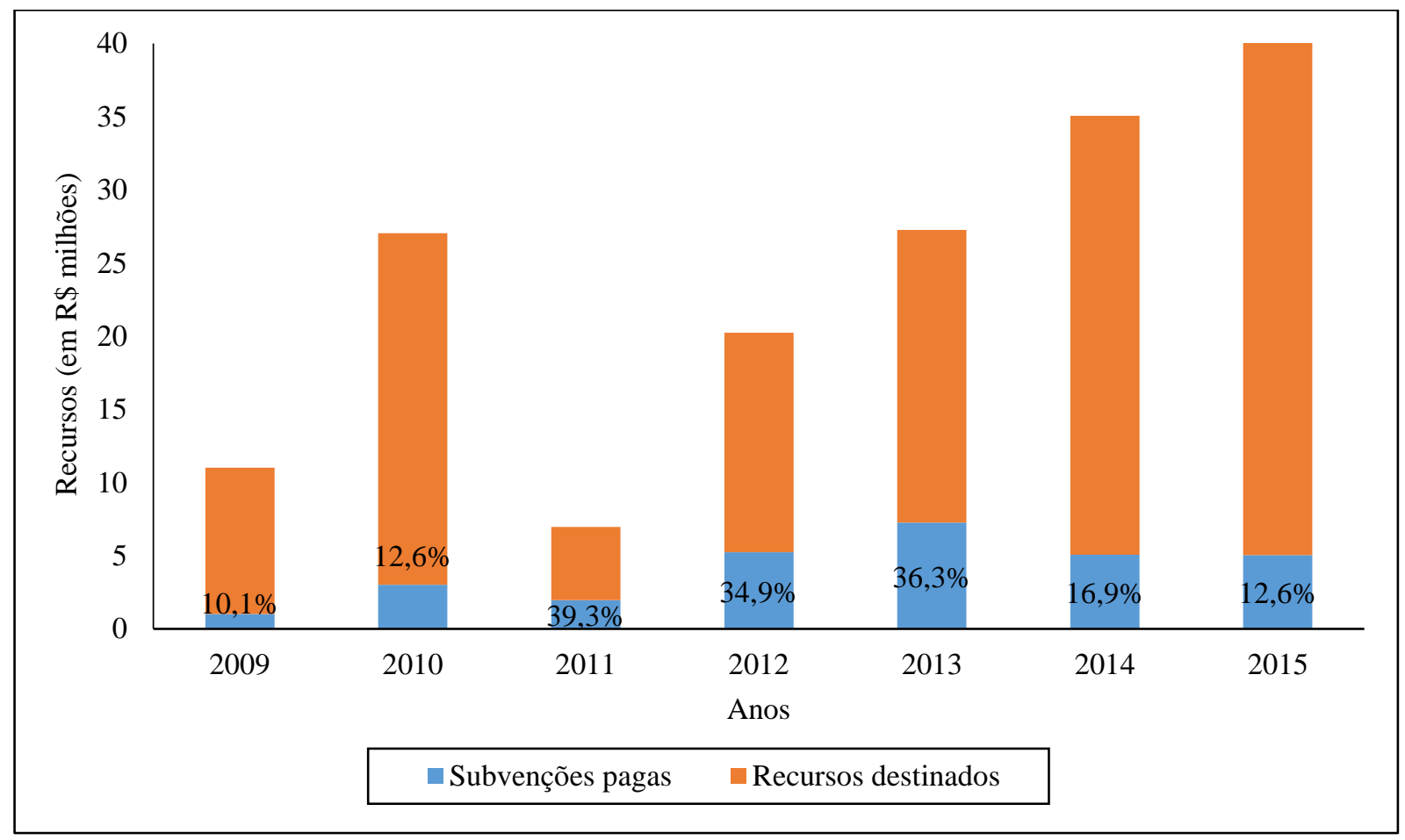

FIGURA 4 - PERCENTUAL DOS RECURSOS DESTINADOS À PGPM-BIO QUE FOI EFETIVAMENTE PAGO, 2009-2015

FONTE: Adaptado de CONAB (2017).

Do total de 144 milhões de reais destinados à política, apenas 19,9\% foram utilizados no pagamento das subvenções. É interessante observar que mesmo que os recursos tenham aumentado ao longo dos anos, principalmente com acréscimos de 10 milhões de reais anuais a partir de 2012, o 
volume de pagamentos se manteve inferior a $40 \%$ do total, o que demonstra que a falta de recursos financeiros não foi um obstáculo para a execução da política.

Moraes (2013) aponta como uma causa para o insucesso da PGPM-Bio o fato de os preços mínimos serem considerados como balizadores para o mercado, pois estão muito aquém, até mesmo, dos mercados informais. Para ela, os custos de produção utilizados para a formulação dos preços não mensuram os serviços ambientais prestados, mas sim, valoram parcialmente o produto e, consequentemente, torna os preços impraticáveis.

Assim, transformar a PGPM-Bio em um instrumento efetivo na busca da sustentabilidade socioambiental se traduz em grande desafio para os gestores da política. Faz-se necessário, portanto, reformulá-la, por meio do abandono de um caráter meramente mercadológico, de recomposição de custos, para, em contrapartida, estabelecer novos métodos de cálculo de pagamento de bônus que incluam variáveis de valoração ambiental, que forneçam maior atratividade aos beneficiários e propiciem a formalização e o fortalecimento dos mercados extrativistas.

Diante do exposto, o próximo tópico se refere às potencialidades da PGPM-Bio para o estado de Goiás com foco na emergência do surgimento de um novo modelo de produção que ressalte as potencialidades naturais do Cerrado desse estado sem levar à degradação ambiental e à exclusão social.

\section{Potencialidades da PGPM-Bio em Goiás para o desenvolvimento sustentável}

A conscientização dos efeitos negativos causados ao bioma Cerrado em virtude de sua incorporação ao sistema predatório de exploração dos recursos naturais torna emergente a prática de ações que visem ao desenvolvimento sustentável. Nesse sentido, busca-se identificar as potencialidades de Goiás para a operacionalização da PGPM-Bio como estratégia de conciliação entre a conservação ambiental, a responsabilidade social e a geração de renda aos agricultores familiares e às comunidades tradicionais.

De acordo com Dias (2006), a noção de desenvolvimento sustentável objetiva a erradicação da pobreza por meio de projetos e políticas sociais que permitam elevar a qualidade de vida da população e satisfazer suas necessidades básicas, com base em princípios orientados para um desenvolvimento harmônico entre sociedade e natureza.

Sachs (2006), em suas reflexões sobre o conceito de desenvolvimento sustentável, acrescenta que este deve ser o reflexo do equilíbrio entre cinco dimensões fundamentais: o ecológico, o social, o econômico, o cultural e o geográfico. 
Dessa forma, nos últimos anos, evidenciam-se os estudos sobre o desenvolvimento sustentável nas atividades econômicas do meio rural, uma vez que tais análises são de suma importância para a construção do desenvolvimento sustentável em nível global. Segundo Zylberstanj, Nassar e Neves (2000), a definição de desenvolvimento rural sustentável surgiu no ano de 1991, em uma reunião da FAO, sigla em inglês que significa Organização das Nações Unidas para a Agricultura e Alimentação. Essa reunião resultou em um documento que trazia a seguinte definição:

O manejo e a conservação da base de recursos naturais e a orientação de mudança tecnológica e institucional, de maneira a assegurar a obtenção e a satisfação contínua das necessidades humanas para as gerações presentes e futuras. Tal desenvolvimento sustentável (na agricultura, na exploração florestal, na pesca) resulta na conservação do solo, da água e dos recursos genéticos animais e vegetais, além de não degradar o ambiente, ser tecnicamente apropriado, economicamente viável e socialmente aceito. (FAO, 1991 apud ZYLBRTDTAJN; NASSAR; NEVES, 2000, p. 264).

Nesse sentido, observa-se que as ações para o desenvolvimento rural sustentável devem promover a diversificação produtiva, com a inclusão dos aspectos social, ambiental e cultural do território, na busca pelo desenvolvimento endógeno que promova, tão somente, a conservação e o convívio harmônico com a natureza. Em consonância a essa nova emergência de se pensar a produção no campo, um dos grandes avanços nacionais na maneira de se pensar o desenvolvimento é a política do desenvolvimento territorial rural, implantada no ano de 2003 pelo então Ministério do Desenvolvimento Agrário.

O estado de Goiás, como área core do bioma Cerrado, apresenta distintas possibilidades naturais para sua inserção nessa nova lógica de exploração sustentável dos recursos naturais. Todavia, ao observarmos sua participação na PGPM-Bio identificamos que a implantação dessa política ainda se demonstra morosa nesse estado. Uma das explicações para essa realidade se dá, como apontamos nos capítulos anteriores, em virtude dos interesses do grande capital agroindustrial, que se apresenta mais atrativo aos pequenos produtores, bem como a falta de mercados formalizados e de cadeias produtivas completas para os produtos florestais não madeireiros da sociobiodiversidade goiana.

Os produtos florestais não madeireiros são de origem animal e vegetal, e podem ser colhidos em seu habitat natural ou em locais onde a domesticação foi iniciada, para o caso em que se retirou uma semente da floresta e, em seguida, houve o cultivo da espécie próximo ao local de residência. Esses produtos podem ser usados na alimentação humana e/ou animal e construção civil, para uso medicinal, usos sociais (uso em rituais religiosos ou como drogas etc.) e/ou ambientais (uso 
ornamental ou para melhoramento do solo), como aditivos alimentares (na forma de corantes, temperos, fermentos etc.), matéria-prima para confecção de utensílios diversos (por exemplo: cestos, verniz, cola etc.) e combustível (ANDEL, 2006).

A importância dos produtos madeireiros não florestais não está apenas em seu valor de uso, mas também no significado que possuem à população que deles se utilizam, seja para subsistência ou para o comércio, sobretudo as pessoas que estão nas áreas rurais. Conforme Andel (2006), 80\% da população que está nos países subdesenvolvidos ou em desenvolvimento utilizam os produtos madeireiros não florestais para suprir as necessidades nutritivas, sanar problemas de saúde, construir suas casas e mobiliá-las e, até mesmo, trabalhar. Em alguns casos, "a extração, processamento e comercialização dos PFNM constituem, muitas vezes, a única forma de emprego disponível nas áreas rurais remotas" (ANDEL, 2006, p. 9) que, apesar de terem alto valor comercial, não são suficientes para remunerar adequadamente as famílias coletoras, haja vista a presença de atravessadores durante o processo de venda. Além da baixa renda, a distância dos centros urbanos torna o custo dos bens de consumo sobremodo elevado, o que impede o seu acesso por parte das populações rurais e aumenta a dependência destas em relação aos recursos naturais. Assim, a relevância social dos produtos florestais não madeireiros é inegável. Entretanto, sua importância econômica é, na maioria das vezes, ignorada. Andel (2006) afirma que:

Ao contrário do que se passa em relação aos produtos madeireiros e agrícolas, não se realiza, em lado algum, uma monitorização ou avaliação dos recursos, cadeias de mercado e contribuição socioeconômica dos PFNM a nível nacional. Apenas os produtos florestais não madeireiros exportados surgem, por vezes, nas estatísticas nacionais. Mesmo assim, o mercado mundial anual de produtos (derivados) de plantas selvagens está estimado em 60 milhões de dólares americanos (US\$) e este mercado continua a crescer cerca de $20 \%$ ao ano. (ANDEL, 2006, p. 11-12).

E no Brasil não é diferente. A pesquisa anual sobre a Produção da Extração Vegetal e da Silvicultura elaborada pelo Instituto Brasileiro de Geografia e Estatística (IBGE) analisa os aspectos econômicos de área, quantidade produzida e valor da produção de alguns produtos florestais em geral, quer madeireiros ou não. Conforme a pesquisa, entre 2009 e 2015, a produção extrativa vegetal goiana representou, em média, cerca de $1,15 \%$ do valor total produzido no Brasil, o que demonstra pouca expressividade no setor. Em 2015, o valor da produção extrativa vegetal goiana esteve altamente concentrado em produtos madeireiros: carvão vegetal $(18,1 \%)$, lenha $(62,5 \%)$ e madeira em tora (12,5\%). Esses percentuais, tidos como oficiais, são passíveis de questionamento haja vista a ausência de formalização dos mercados para os produtos florestais não madeireiros no estado, apesar da gama de oportunidades existentes. Veiga e Ehlers (2010) evidenciam o potencial do Cerrado: 
Os Cerrados, que ocupam um quarto do nosso território, são o segundo maior bioma brasileiro (após a Amazônia) e concentram nada menos que um terço da biodiversidade nacional e 5\% da flora e da fauna mundiais. A flora dos Cerrados é considerada a mais rica do mundo entre as savanas. A adaptação destas plantas aos solos, ao clima e aos predadores característicos dos ambientes dos Cerrados faz delas "bancos gênicos de muito maior valor do que o atribuído e merecem ter importância muito maior do que apenas a de produzir carvão e enormes áreas de cultivo (...)". (VEIGA; EHLERS, 2010, p. 294).

A fim de corroborar a assertiva sobre a riqueza da biodiversidade goiana, o Quadro 1 apresenta os produtos florestais não madeireiros nativos do Cerrado com maior relevância socioeconômica para o estado de Goiás. Os produtos estão nomeados de acordo com o nome comum utilizado pela população goiana, acrescidos de sua nomenclatura científica, da época ideal para a coleta e dos tipos de vegetação de ocorrência ${ }^{6}$.

Dos produtos florestais não madeireiros elencados no Quadro 1, apenas quatro estão presentes na pauta de subvenções da PGPM-Bio para Goiás: o baru, a macaúba, a mangaba e o pequi. Esses produtos são a possibilidade imediata para a inserção de Goiás nessa política, contudo, nos estudos realizados pelo IBGE, apenas a mangaba e o pequi têm suas variáveis econômicas analisadas.

O baru (Dipteryx alata) é uma planta nativa do Cerrado que tem porte médio de 15 metros e, atualmente, é utilizada quase que exclusivamente pelo extrativismo. No Cerrado goiano, o baruzeiro ocorre nas mesorregiões do noroeste e do norte goiano e alguns dos municípios produtores de baru e seus derivados são: Caiapônia, Caldazinha, Diorama, Pirenópolis e Orizona.

O baruzeiro inicia sua fase fértil a partir dos 06 anos, em safras intermitentes, ou seja, dispõe de uma safra boa e de outra ruim ou "no que diz respeito à utilização comercial, apresenta uma safra produtiva a cada 2 anos". (CARRAZZA; D'ÁVILA, 2010, p. 12). Em relação ao rendimento do baruzeiro, Sano, Ribeiro e Brito (2004) afirmam que, diariamente, durante a safra, dos frutos caídos no chão podem ser coletados de 135 a 180 quilos do fruto por pessoa.

Na PGPM-Bio, o baru deve ser subvencionado na forma de amêndoa. Esta corresponde a $5 \%$ da massa do fruto, o que significa que de 135 quilos do fruto, serão produzidos apenas 6,75 quilos de amêndoa. A quebra do baru é atividade trabalhosa devido à dureza de sua casca e na maioria dos casos, é feita pelo próprio coletor em maquinário improvisado com foice ou machado, o que diminui a produtividade do trabalho: constatou-se que, por dia, manualmente, são quebrados, em média, 2 quilos de baru por pessoa, o que demonstra que, para cada um dia de coleta, são

\footnotetext{
${ }^{6}$ Para saber mais sobre as fitofisionomias do Cerrado, consulte o sítio do Instituto Chico Mendes de Conservação da Biodiversidade (ICMBio) na Internet: 〈https://goo.gl/vHAb1Z〉.
} 
necessários três dias para a quebra. Após retirada, a amêndoa deve ser refrigerada (SANO; RIBEIRO; BRITO, 2004). Hipoteticamente, caso haja a coleta durante 10 dias, o valor máximo obtido em um mês pela venda da amêndoa do baru seria de, aproximadamente, R\$ 892,35 (oitocentos e noventa e dois reais e trinta e cinco centavos), conforme o preço mínimo estipulado pela PGPM-Bio por DAP familiar. Tal valor demonstra que a PGPM-Bio não é capaz de remunerar adequadamente o extrativista, uma vez que não considera todos os custos envolvidos no processo, como a mão de obra para a quebra, o maquinário, o armazenamento, e acaba por estimular a comercialização informal.

Desse modo, as pessoas que praticam a coleta do baru necessitam encontrar maneiras de aproveitar integralmente o fruto, para elevar o rendimento por elas auferido e, assim, conservaremos a riqueza ambiental que as rodeia, desfrutando plenamente de todos os seus benefícios.

A macaúba (Acrocomia aculeata) é uma espécie de palmeira encontrada no Cerrado e em florestas abertas, que pode atingir de 10 a 15 metros e que produz frutos a partir dos 06 anos. Ocorrências naturais da macaúba em Goiás foram encontradas nos municípios de Santa Cruz de Goiás, São Miguel do Passa Quatro, Paraúna, Jandaia, Indiara, localizados na mesorregião do sul goiano, e São Francisco de Goiás e Jaraguá, ambos localizados na mesorregião do centro goiano. 
QUADRO 1 - PRINCIPAIS PRODUTOS FLORESTAIS NÃO MADEIREIROS NATIVOS DO CERRADO COM IMPORTÂNCIA SOCIOECONÔMICA PARA GOIÁS

\begin{tabular}{|c|c|c|c|c|}
\hline Nome comum & Nome científico & Época de coleta & Ocorrência & Importância socioeconômica \\
\hline Araticum & Annona crassiflora & Fevereiro e março & $\begin{array}{l}\text { Cerrado sentido } \\
\text { restrito, cerradão e } \\
\text { cerrado aberto }\end{array}$ & $\begin{array}{l}\text { Uso alimentício: fabricação de sorvetes, picolés, bebidas, bolos. Uso medicinal: possui antioxidantes e ajuda na } \\
\text { prevenção de doenças degenerativas. Na medicina popular é usado para combater reumatismo, úlcera e câncer de } \\
\text { pele. Demais usos: ornamental. }\end{array}$ \\
\hline Baru & Dipteryx alata & Agosto a outubro & $\begin{array}{l}\text { Mata calcária, } \\
\text { cerradão e cerrado } \\
\text { sentido restrito }\end{array}$ & $\begin{array}{l}\text { Uso alimentício: fabricação de paçoca, farinha, doces ou consumido in natura ou torrado. Uso medicinal: o óleo } \\
\text { extraído é antirreumático e possui propriedades sudoríferas, tônicas e reguladoras da menstruação. Demais usos: a } \\
\text { casca pode ser usada como carvão vegetal e também na confecção de artesanatos. }\end{array}$ \\
\hline Buriti & Mauritia flexиоsa & Outubro a março & $\begin{array}{l}\text { Mata galeria, várzea e } \\
\text { vereda }\end{array}$ & $\begin{array}{l}\text { Uso alimentício: os frutos são consumidos in natura ou utilizados em doces, óleos, sorvetes, geleias etc. Uso } \\
\text { medicinal: na medicina popular, é usado para cicatrização de feridas e queimaduras, aliviar a dor de picadas de } \\
\text { insetos, amenizar problemas respiratórios e curar picadas de cobras. Uso cosmético: o óleo possui antioxidantes e } \\
\text { vitaminas que servem para a produção de sabonetes, hidratantes, xampus e, também, como proteção solar. Demais } \\
\text { usos: os talos das folhas são usados para a fabricação de móveis, brinquedos, tapitis etc. O caule é utilizado para } \\
\text { construir cercas e paredes de casas. As folhas são usadas em cestos, esteiras, utensílios, cordas, para cobrir } \\
\text { telhados etc. }\end{array}$ \\
\hline Cagaita & Eugenia dysenterica & $\begin{array}{l}\text { Setembro a } \\
\text { novembro }\end{array}$ & $\begin{array}{l}\text { Cerrado sentido } \\
\text { restrito e cerradão }\end{array}$ & $\begin{array}{l}\text { Uso alimentício: a polpa pode ser consumida in natura ou usada para fazer doces, geleias, licores, refrescos, } \\
\text { sorvetes, sucos e até mesmo vinagre e álcool. Uso medicinal: na medicina popular, as folhas são usadas para fazer } \\
\text { garrafadas, para combater diarreia e problemas cardíacos e para o preparo de chás, usados como anticonstipantes } \\
\text { e, também, no combate ao diabetes e à icterícia. }\end{array}$ \\
\hline $\begin{array}{r}\text { Cajuzinho-do- } \\
\text { cerrado }\end{array}$ & Anacardium nanum & Setembro e outubro & $\begin{array}{l}\text { Cerrado sentido } \\
\text { restrito e cerradão }\end{array}$ & $\begin{array}{l}\text { Uso alimentício: o fruto pode ser consumido in natura ou em sucos, bebidas ou doces. Uso medicinal: o óleo da } \\
\text { castanha contém cardol e ácido anacárdico e é utilizado como antisséptico e cicatrizante. }\end{array}$ \\
\hline Capim dourado & Syngonanthus nitens & Setembro e outubro & $\begin{array}{l}\text { Campos úmidos das } \\
\text { veredas }\end{array}$ & Uso artesanal: confecção de bolsas, bijuterias e itens de decoração. \\
\hline Coquinho azedo & Butia capitata & Outubro a janeiro & $\begin{array}{l}\text { Cerrado sentido } \\
\text { restrito e cerrado } \\
\quad \text { rupestre }\end{array}$ & $\begin{array}{l}\text { Uso alimentício: os frutos podem ser consumidos in natura ou na forma de sucos, picolés, geleias, licores, bolos e } \\
\text { sorvetes. As amêndoas são utilizadas na fabricação de doces, pães, biscoitos, canjica e óleos. Demais usos: as } \\
\text { folhas são utilizadas na fabricação de vassouras, cestos, cordas, cobertura de casas e estofados. }\end{array}$ \\
\hline Favela & Dimorphandra mollis & Abril a agosto & $\begin{array}{c}\text { Cerrado sentido } \\
\text { restrito, campos } \\
\text { sujos, campos limpos, } \\
\text { cerradão e matas de } \\
\text { encostas }\end{array}$ & $\begin{array}{l}\text { Uso alimentício: é usada como aromatizante, espessante e estabilizante. Uso medicinal: na medicina popular, é } \\
\text { usada como anti-hemorrágico, no tratamento de hemorroidas, varizes e hematomas e como cicatrizante. Uso } \\
\text { farmacêutico e cosmético: é a origem de princípios ativos bioflavonoides, como a rutina e a quercetina. Demais } \\
\text { usos: é usada também no paisagismo, na confecção de caixas, de forros, de brinquedos, de compensados, de } \\
\text { painéis, de postes de cerca, assim como para lenha e carvão. }\end{array}$ \\
\hline Gueroba & Syagrus oleracea & Junho a janeiro & $\begin{array}{l}\text { Cerradão, mata } \\
\text { galeria e mata ciliar }\end{array}$ & $\begin{array}{l}\text { Uso alimentício: como alimento humano são usados a polpa, a amêndoa do coco e o palmito amargo. As folhas e } \\
\text { cocos são usados para alimentar animais domésticos, como gado, cavalos e porcos. Uso medicinal: na medicina } \\
\text { popular, o óleo do bicho do coco é usado para curar otites e rachaduras nos pés. As flores são usadas no tratamento } \\
\text { da bronquite e as raízes no tratamento de dores na coluna. O óleo da amêndoa possui propriedades medicinais e } \\
\text { cosméticas. }\end{array}$ \\
\hline
\end{tabular}


Continuação Quadro 1

\begin{tabular}{|c|c|c|c|c|}
\hline Nome comum & Nome científico & Época de coleta & Ocorrência & Importância socioeconômica \\
\hline Jatobá & Hymenaea stigonocarpa & $\begin{array}{l}\text { Setembro a } \\
\text { novembro }\end{array}$ & $\begin{array}{l}\text { Cerrado sentido } \\
\text { restrito e cerradão }\end{array}$ & $\begin{array}{l}\text { Uso alimentício: a polpa farinácea do fruto pode ser consumida in natura e na forma de vitaminas, geleia, licor, } \\
\text { farinha para bolos, pães e mingaus. A resina quando misturada à cachaça apresenta propriedades tônicas. Uso } \\
\text { medicinal: a resina e a polpa são usadas no combate de afecções pulmonares em geral, dores e cólicas estomacais, } \\
\text { vermífugo e antidiarreico, antioxidante, diurético, expectorante, hepatoprotetor, estimulante, energético, } \\
\text { fortalecedor do sistema imunológico, estimulante utilizado para melhorar o desempenho sexual. Demais usos: as } \\
\text { sementes de jatobá, fontes de galactomananos e xiloglucanos, possuem características emulsificantes, espessantes, } \\
\text { dispersantes e estabilizadoras de suspensão ou emulsão, que são de grande interesse da indústria de cosméticos, } \\
\text { indústria farmacêutica, de alimentos, papel, na coagulação da borracha no processo de transformação do látex. A } \\
\text { madeira é muito apreciada na construção civil e naval. A árvore é bem recomendada para recuperação de áreas. }\end{array}$ \\
\hline Macaúba & Acrocomia aculeata & Julho a janeiro & $\begin{array}{l}\text { Mata calcária e } \\
\text { cerradão }\end{array}$ & $\begin{array}{l}\text { Uso alimentício: a polpa pode ser consumida in natura e, além disso, juntamente com a farinha retirada de seus } \\
\text { frutos podem ser usadas para fazer suco, sorvete, barra de cereais, bolos, pães e doces. O óleo da amêndoa é usado } \\
\text { na produção de margarina. Uso químico e cosmético: o óleo da amêndoa pode ser usado na fabricação de sabão, } \\
\text { sabonete, cosméticos e biodiesel. Demais usos: as folhas servem para a confecção de redes e linhas de pescaria. }\end{array}$ \\
\hline Mangaba & Hancornia speciosa & Outubro a dezembro & $\begin{array}{l}\text { Cerrado sentido } \\
\text { restrito e cerradão }\end{array}$ & $\begin{array}{l}\text { Uso alimentício: os frutos podem ser consumidos in natura ou podem ser transformados em polpas, geleias, } \\
\text { sorvetes, sucos, doces, bolos, biscoitos e licores. Uso medicinal: na medicina popular, a casca é utilizada contra } \\
\text { doenças de pele e como estimulante de funções hepáticas, o chá da folha da mangabeira é usado para combater } \\
\text { cólicas menstruais e o leite é usado para combater a tuberculose e para o tratamento de úlceras. Demais usos: a } \\
\text { madeira poder servir como lenha e, durante a Segunda Guerra Mundial, o leite foi usado para produção de } \\
\text { borracha. }\end{array}$ \\
\hline Murici & Byrsonima verbascifolia & Novembro a março & $\begin{array}{l}\text { Cerrado sentido } \\
\text { restrito e cerradão }\end{array}$ & $\begin{array}{l}\text { Uso alimentício: os frutos podem ser consumidos in natura ou beneficiados em forma de sucos, picolés, licores, } \\
\text { geleias, doces, conservas e em forma de farinha. Uso medicinal: o murici é usado, na medicina popular, como } \\
\text { antifebrífugo, antibacteriano e antifúngico. Sua casca, rica em taninos, é muito utilizada popularmente como } \\
\text { cicatrizante e anti-inflamatório. O chá da casca do caule apresenta atividade adstringente nas diarreias e } \\
\text { disenterias. }\end{array}$ \\
\hline Pequi & Caryocar brasiliense & Outubro a janeiro & $\begin{array}{l}\text { Cerrado sentido } \\
\text { restrito, cerradão e } \\
\text { mata calcária }\end{array}$ & $\begin{array}{l}\text { Uso alimentício: o caroço pode ser consumido in natura ou cozido. A polpa é utilizada para extração do óleo, na } \\
\text { produção de geleias, doces, licores, cremes, sorvetes, farofas, pamonhas e ração para porcos e galinhas. Da } \\
\text { amêndoa pode-se extrair óleo e também ser consumida in natura ou torrada e utilizada no preparo de paçocas, } \\
\text { bolos, doces e pamonhas. Uso medicinal: o fruto auxilia no combate ao envelhecimento e na prevenção às doenças } \\
\text { associadas à visão; a amêndoa é utilizada na fabricação de um óleo que possui ação anti-inflamatória, cicatrizante } \\
\text { e gastroprotetora. Demais usos: a madeira é utilizada na fabricação de móveis rústicos, caibros, postes, esteios, }\end{array}$ \\
\hline Pitomba & Talisia esculenta & Outubro a janeiro & $\begin{array}{l}\text { Mata calcária e } \\
\text { cerradão }\end{array}$ & $\begin{array}{l}\text { Uso alimentício: pode ser consumida in natura ou beneficiada na forma de licores ou polpa. Uso medicinal: na } \\
\text { medicina popular, as sementes são tidas como antidiarreicas e usadas como adstringentes, o chá das sementes é } \\
\text { utilizado para amenizar os problemas de desidratação e o chá das folhas é indicado para as dores nos quadris e } \\
\text { para os problemas renais. }\end{array}$ \\
\hline
\end{tabular}

FONTES: CERRATINGA (2017). COSTA et al. (2016). GUSMÃO; VIEIRA; FONSECA (2006). ISPN (2017). MESQUITA et al. (2007). SILVA (2013). SILVA et al. (1992). SOUZA; NASSER; SOARES (2013). 
Apesar da elevada variabilidade na quantidade e no peso dos frutos da macaúba, estima-se que cada palmeira produza de 70 a 80 quilos de macaúba por ano-safra e que a capacidade de coleta das famílias seja de 12 a 15 sacas que variam entre 25 e 30 quilos por semana (BRASIL, 2014). Assim, hipoteticamente, em um mês, a renda máxima que uma família alcançaria com a venda de, aproximadamente, 1.485 quilos de macaúba seria de $\mathrm{R} \$ 816,75$ (oitocentos e dezesseis reais e setenta e cinco centavos), conforme o preço mínimo estipulado pela PGPM-Bio por DAP.

A mangabeira (Hancornia speciosa) é uma árvore que ocorre nos biomas Cerrado e Caatinga e em alguns lugares da Amazônia e, em decorrência disso, apresenta diferenças no tamanho das árvores (que podem variar entre 2 e 10 metros) nos períodos de floração e de frutificação e na quantidade dos frutos produzidos, que em alguns casos pode ser de até 800 unidades em uma única planta. Em média, o peso de uma mangaba é de cerca de 20 gramas. (LIMA; SCARIOT, 2010).

A mangaba é considerada uma das cadeias mais expressivas entre os produtos da sociobiodiversidade segundo critérios de seu significado social, valor econômico, importância ambiental e representatividade territorial. Os estados com maior produção de mangaba são Sergipe, Minas Gerais e Bahia. No ano de 2015, segundo os dados do IBGE, a comercialização da mangaba em Goiás correspondeu a $0,11 \%$ de todo o valor de produção da extração vegetal, o que correspondeu a R\$28.000,00 (vinte e oito mil reais), resultado considerado inexpressivo. Os municípios goianos que registraram produção e venda de mangaba no período analisado são: Rianápolis, localizado na mesorregião do centro goiano, e Goiás, localizado na mesorregião do noroeste goiano.

De acordo com Vieira et al. (2006), uma mangabeira produz, em média, 100 quilos de fruto por ano e, conforme Oliveira (2016), em uma hora de trabalho é possível coletar, em média, de 5 a 10 quilos de mangaba. Dessa forma, hipoteticamente, com uma jornada diária de 8 horas por dia, um extrativista poderia coletar, em média, cerca de 60 quilos de fruto por dia, o equivaleria a, aproximadamente, 1.560 quilos de mangaba e uma renda máxima de $\mathrm{R} \$ 2.542,80$ (dois mil, quinhentos e quarenta e dois reais e oitenta centavos) em um mês, conforme o preço mínimo vigente na pauta da PGPM-Bio.

O pequi (Caryocar brasiliense) tem vida útil estimada em 50 anos. Entra na fase produtiva ao completar oito anos de vida e sua floração ocorre entre os meses de setembro a outubro. A frutificação acontece de outubro a fevereiro e a produção variável pode chegar a 1.000 frutos por pé (SILVA, 2011).

Dos produtos madeireiros não-florestais, o pequi é o que de maior importância para Goiás. Segundo dos dados do IBGE, em 2015, o pequi gerou um valor de produção superior a R $\$ 1,6$ 
milhão (um milhão e seiscentos mil reais) e, entre 2014 e 2015, houve importante incremento de $32 \%$ no montante comercializado do fruto. Os municípios goianos que mais extraem o pequi são: Sítio d'Abadia, Damianópolis e Mambaí, localizados na mesorregião do leste goiano, e Santa Terezinha de Goiás e Campos Verdes, ambos localizados na mesorregião do norte goiano.

Em relação à produtividade do pequi, "no sudeste de Goiás, um pequizeiro adulto pode produzir até 350 frutos por safra, e em outras áreas do estado são relatadas plantas produzindo mais de 3400 frutos" (OLIVEIRA, 2010, p. 24). O peso dos frutos é variável e a quantidade de caroços também: podem pesar entre 30 e 400 gramas e possuir até 6 caroços. Em um dia de trabalho, uma família consegue coletar até 60 quilos de caroços (OLIVEIRA, 2010). Os frutos podem pesar até mais de um quilo e os caroços até 200 gramas. (VIEIRA et al., 2006). Assim, hipoteticamente, pode-se inferir que, diariamente, uma família é capaz de coletar cerca de 300 quilos de fruto do pequi e, em um mês, após 6 dias de trabalho semanal, 7.800 quilos do fruto que, de acordo com o preço mínimo estipulado pela PGPM-Bio, resultaria em um rendimento mensal de $\mathrm{R} \$ 4.368,00$ para a família. No entanto, o limite máximo para recebimento de subvenção é de R \$2.000,00 por DAP.

O pequi é o único produto presente na pauta da PGPM-Bio que possui comercialização pelas Centrais de Abastecimento de Goiás S.A. (CEASA - GO). Conforme os boletins diários de cotação de preços, em dezembro de 2016, durante o auge da safra, o preço médio de uma caixa com 32 quilos de pequi foi de $\mathrm{R} \$ 51,00$ e o preço médio de um quilo de fruto do pequi foi de $\mathrm{R} \$ 1,59$. Já em abril de 2017, período da entressafra, o preço médio de uma caixa com 32 quilos de pequi foi de $\mathrm{R} \$ 40,00$ e o preço médio de um quilo de fruto do pequi foi de R\$ 1,25 (CEASA - GO, 2017). Superficialmente, tais valores revelam que a subvenção do fruto do pequi não é necessária em Goiás, contudo, conforme Gulias et al. (2008), a cadeia produtiva do pequi, cuja maioria das etapas encontra-se na informalidade, apresenta intermediários/atravessadores no processo de comercialização do fruto, o que impede a precisão do valor recebido pelo extrativista. Para o caso do pequi, portanto, é de suma importância a formalização de toda a cadeia produtiva.

Enfim, mesmo com a variabilidade de plantas nativas do Cerrado e de grande incidência em solo goiano, a PGPM-Bio ainda não subvencionou nenhum produto em Goiás. Possíveis causas para o insucesso atual da política nesse estado podem estar ligadas à inexistência de mercados formais para que se façam as vendas com notas fiscais, pois a maior parcela da comercialização dos produtos extrativos é feita em áreas rurais e por meio de atravessadores; a distância da localização de alguns produtos das áreas de extração dos grandes centros comerciais, como Goiânia, Anápolis e Brasília; o desconhecimento da política; ausência de estudos por parte do poder público para mapear as áreas produtoras; preço pouco atraente frente à burocracia para o acesso à política; a cultura da doação, sobretudo em períodos de safra, pois com a grande oferta dos produtos os 
coletores buscam produtos para consumo próprio e acabam por compartilhar os frutos com a comunidade local, sem atribuir valor de troca ao produto; e, especificamente para o baru, há o empecilho da quebra da castanha, que exige mão de obra intensiva e resulta em pouca produtividade, além de tornar o preço da amêndoa elevado, o que evidencia a ineficiência da política para esse produto.

\section{Considerações finais}

O debate acerca da conservação ambiental está em voga nos dias atuais e é tema preocupante para todas as nações do mundo. De tal inquietação decorrem medidas que foram criadas com a finalidade de amenizar os efeitos negativos da intervenção inadequada do homem na natureza. Tais medidas, em sua grande parte, devem ser tomadas pelo poder público, por meio de suas prerrogativas reguladoras e estabilizadoras. Entretanto, a cooperação entre Estado, sociedade civil e setor privado tem sido de grande eficácia para a elaboração de políticas que fomentem a geração de riqueza econômica e, simultaneamente, preservem o meio ambiente e a cultura.

Dentre as iniciativas adotadas está a Política de Garantia de Preços Mínimos para Produtos da Sociobiodiversidade (PGPM-Bio), que visa garantir o consumo e a conservação de quinze espécies vegetais extrativas presentes nos seis biomas brasileiros, dentre eles o Cerrado, que recobre toda a área territorial do estado de Goiás.

Por longo período, o Cerrado, sobretudo em solo goiano, foi palco para o uso de técnicas de modernização agrícola para o cultivo de monoculturas cujas técnicas utilizadas elevaram a produtividade das commodities mas, em contrapartida, levaram à degradação ambiental, como a exaustão do solo, a contaminação do ambiente pelo uso de agrotóxicos e fertilizantes químicos, o descontrole de pragas e, até mesmo, a perda de algumas identidades culturais por meio do descaso com as tradições locais, ocasionado pela intensa migração proveniente das regiões Sul e Sudeste do país, que trouxeram e imbuíram suas práticas particulares nas regiões de intenso agronegócio.

Nesse contexto, a PGPM-Bio se revela como importante instrumento na recuperação e na conservação ambiental. Os quatro produtos elencados, acrescidos do buriti, como um futuro componente da pauta para Goiás, apresentam formas de aproveitamento das plantas em sua integralidade e são importantes componentes da cultura goiana, como o pequi, fruto nacionalmente reconhecido como um símbolo da culinária goiana. A conservação ambiental pode ocorrer, dentre outras maneiras, através do manejo adequado das espécies nativas do Cerrado com vistas a possibilitar a manutenção da produtividade da planta para outras safras e, também, o equilíbrio do 
ecossistema; do reflorestamento com a utilização de plantas nativas, quando da combinação de técnicas modernas dos sistemas de integração lavoura-pecuária-floresta; e, ainda, na perpetuação das tradições locais em relação ao cuidado com a natureza e ao aproveitamento dos subprodutos dos frutos nativos para confecção de artigos artesanais.

No entanto, a PGPM-Bio em Goiás necessita de maiores estímulos para que seus benefícios sejam amplamente difundidos, desde o mapeamento das áreas produtoras, a divulgação abrangente da política até a criação de estímulos para formalização de toda a cadeia produtiva. Para o Brasil, como um todo, existe a necessidade da melhoria dos preços, com novas metodologias para quantificar não apenas os custos de produção, mas sim o real pagamento pelos serviços ambientais e a valoração, também, dos benefícios sociais resultantes da atividade extrativa consciente.

\section{Referências}

ABRAMOVAY, R. Muito além da economia verde. São Paulo: Abril, 2012.

ALMEIDA, G. S.; VIEIRA JUNIOR, P. A.; RAMOS, P. Os programas de desenvolvimento econômico do centro-oeste brasileiro e suas consequências: anos 60 e 70. In: CONGRESO DE LA ASOCIACIÓN LATINOAMERICANA DE SOCIOLOGÍA RURAL. 7. 2006. Quito. Anais... Quito: 2006.

ANDEL, T. van. Produtos florestais não-madeireiros: o valor das plantas selvagens. Wageningen--NL: Fundação Agromisa e CTA, 2006. Disponível em: <https://goo.gl/Dz4Bc2>. Acesso em: 03 maio 2017.

BRASIL. Decreto-Lei $\mathbf{n}^{0}$ 79, de 19 de dezembro de 1966. Institui normas para a fixação de preços mínimos e execução das operações de financiamento e aquisição de produtos agropecuários e adota outras providências. Disponível em: 〈https://goo.gl/ftH8EB>. Acesso em: 08 mar. 2017.

Lei $n^{0}$ 8.171, de 17 de janeiro de 1991. Dispõe sobre a política agrícola. Disponível em: <https://goo.gl/ZSeOpV>. Acesso em: 08 mar. 2017.

Lei $\mathbf{n}^{\circ}$ 8.427, de 27 de maio de 1992. Dispõe sobre a concessão de subvenção econômica nas operações de crédito rural. Disponível em: 〈https://goo.gl/rPojnF>. Acesso em: 08 mar. 2017.

Lei $\mathbf{n}^{\circ}$ 11.326, de 24 de julho de 2006. Estabelece as diretrizes para a formulação da Política Nacional da Agricultura Familiar e Empreendimentos Familiares Rurais. Disponível em: <https://goo.g1/ZSeOpV>. Acesso em: 08 mar. 2017.

Lei n. 11.775, de 17, de setembro de 2008. Institui medidas de estímulo à liquidação ou regularização de dívidas originárias de operações de crédito rural e de crédito fundiário; altera as Leis $\mathrm{n}^{\text {os }} 11.322$, de 13 de julho de 2006, 8.171, de 17 de janeiro de $1991,11.524$, de 24 de setembro de 2007, 10.186, de 12 de fevereiro de 2001, 7.827, de 27 de setembro de 1989, 10.177, de 12 de janeiro de 2001, 11.718, de 20 de junho de 2008, 8.427, de 27 de maio de 1992, 10.420, de 10 de 
abril de 2002, o Decreto-Lei $n^{\circ} 79$, de 19 de dezembro de 1966, e a Lei $n^{\circ} 10.978$, de 7 de dezembro de 2004; e dá outras providências. Disponível em: <https://goo.gl/jgpztR>. Acesso em: 08 mar. 2017.

Ministério da Agricultura, Pecuária e Abastecimento. Portaria no 123, de 05 de julho de 2016. Diário Oficial da União, Brasília, DF, 06 jul. 2016. Seção 1, p. 2-3. Disponível em: <https://goo.gl/ZVLpqZ>. Acesso em: 21 mar. 2017.

Ministério do Desenvolvimento Agrário. Técnicas para adoção de boas práticas de manejo para o extrativismo do fruto da macaúba/bocaiúva (Acrocomia spp.). Brasília: MDA, 2014. Disponível em: <https://goo.gl/zUXMzB>. Acesso em: 04 mai. 2017.

Ministério do Desenvolvimento Agrário. Ministério do Meio Ambiente. Ministério do Desenvolvimento Social e Combate à Fome (Grupo de Coordenação). Plano Nacional de Promoção das Cadeias de Produtos da Sociobiodiversidade. Brasília: Grupo de Coordenação, 2009. Disponível em: 〈https://goo.gl/uaBhBq>. Acesso em: 05 mar. 2017.

Ministério do Meio Ambiente. O bioma Cerrado. Disponível em: <http://www.mma.gov.br/biomas/Cerrado>. Acesso em: 28 mar. 2017.

CALDERON, R. A. Mercado de produtos florestais não madeireiros na Amazônia brasileira. 2013. 97 f. Tese (Doutorado em Ciências Florestais)- Departamento de Engenharia Florestal, Universidade de Brasília, Brasília, 2013. Disponível em: 〈https://goo.gl/TNwT2q>. Acesso em: 22 mar. 2017.

CARRAZZA, L. R.; D'ÁVILA, J. C. C. Manual tecnológico de aproveitamento integral do fruto do baru (Dipteryx alata). 2. ed. Brasília: ISPN, 2010. Disponível em: <http://www.ispn.org.br/arquivos/Mont_Baru0062.pdf>. Acesso em: 02 maio 2017.

CEASA-GO. Centrais de Abastecimento de Goiás S.A. Cotação diária. Disponível em: <http://www.ceasa.goias.gov.br/post/ver/207327/cotacoes-diarias-2016>. Acesso em: 04 maio 2017.

CERRATINGA. Espécies. Disponível em: 〈http://www.cerratinga.org.br/>. Acesso em: 02 maio 2017.

CONAB. Companhia Nacional de Abastecimento. Dados de pagamento de subvenção. Brasília: Conab, [s. d.]. Disponível em: <https://goo.gl/RrVF92>. Acesso em: 15 mar. 2017.

Manual de operações Conab: Título 35 - Subvenção Direta ao Produtor Extrativista (SDPE). Brasília: Conab, 2015. Disponível em: <http://www.conab.gov.br/conabweb/moc.php>. Acesso em: 09 mar. 2017.

Sociobiodiversidade.

Disponível

em:

<http://www.conab.gov.br/conteudos.php?a=1638\&t=2>. Acesso em: 17 mar. 2017.

COSTA, C. B. et al. Análise de viabilidade da produção de semente e polpa de jatobá (Hymenaea spp) na região sul de Goiás. Ciência Florestal, Santa Maria, v. 26, n. 3, p. 1023-1036, jul.-set. 2016. Disponível em: <https://goo.gl/Qq2waH>. Acesso em: 02 maio 2017.

DIAS, R. Gestão Ambiental: responsabilidade social e sustentabilidade. São Paulo: Atlas, 2006. 
EMBRAPA. Empresa Brasileira de Pesquisa Agropecuária. Cerrados: conhecimento, tecnologia e compromisso ambiental. Planaltina, DF: Embrapa, 2005.

GRAZIANO NETO, F. Questão agrária e ecologia: crítica da agricultura moderna. São Paulo: Brasiliense, 1985.

GRUDEM, W.; ASMUS, B. A pobreza das nações: uma solução sustentável. Traduzido por Lucas G. Freire. São Paulo: Vida Nova, 2016.

GUSMÃO, E.; VIEIRA, F. A.; FONSECA, E. M. da. Biometria de frutos e endocarpos de murici (Byrsonima verbascifolia Rich. Ex A. Juss.). Cerne, Lavras, v. 12, n. 1, p. 84-91, jan.-mar. 2006. Disponível em: <https://goo.gl/mJB7Lw>. Acesso em: 03 maio 2017.

HOMMA, A. K. O. Extrativismo vegetal ou plantio: qual a opção para a Amazônia? Estud. av., São Paulo, v. 26, n. 74, p. 167-186, 2012. Disponível em 〈https://goo.gl/TL77VZ〉. Acesso em: 22 mar. 2017.

IBGE. Instituto Brasileiro de Geografia e Estatística. Sistema IBGE de Recuperação Automática. Disponível em: <https://goo.gl/Tno1mj>. Acesso em: 28 mar. 2017.

ISPN. Instituto Sociedade, População e Natureza. Publicações: boas práticas de manejo para o extrativismo sustentável. Disponível em: <http://www.ispn.org.br/>. Acesso em: 02 maio 2017.

LIMA, I. L. P; SCARIOT, A. Boas práticas de manejo para o extrativismo sustentável da mangaba. Brasília: Embrapa, 2010. Disponível em: <http://www.ispn.org.br/arquivos/Mangaba1.pdf>. Acesso em: 02 maio 2017.

MACIEL, D. P. Estado e território na hinterlândia brasileira: as ações da Fundação Brasil Central (FBC) - 1943-1967. In: SILVA, Ademir Luiz da; OLIVEIRA, Eliézer Cardoso de Oliveira; MELO, Marcelo de (Orgs.). Território, cidades e cultura no Cerrado. Anápolis: Universidade Estadual de Goiás, 2012.

MEA. Millennium Ecosystem Assessment. Ecosystems and human well-being: synthesis. Washington, D.C.: Island Press, 2005. Disponível em: <https://goo.gl/9DKrdE>. Acesso em: 22 mar. 2017.

MESQUITA, M. A. M. et al. Caracterização de ambientes com alta ocorrência natural de araticum (Annona crassiflora Mart.) no estado de Goiás. Rev. Bras. Frutic., Jaboticabal, v. 29, n. 1, p. 1519, abr. 2007. Disponível em: <https://goo.gl/4HXm2b>. Acesso em: 02 maio 2017.

MORAES, B. G. M. de. Conjuntura de mercado e intervenção governamental: o caso da PGPM-Bio para o pequi. 42 f. Relatório Final de Estágio Supervisionado Obrigatório (Graduação em Gestão do Agronegócio)- Universidade de Brasília, Campus Planaltina, Brasília, 2013. Disponível em: <https://goo.gl/k9Jy48>. Acesso em: 09 mar. 2017.

OLIVEIRA, K. S. Comunidades extrativistas e o uso da biotecnologia vegetal como alternativa à conservação da mangabeira (Hancornia speciosa Gomes). 2016. 97 f. Dissertação (Mestrado em Desenvolvimento e Meio Ambiente) - Centro de Biociências, Universidade Federal do Rio Grande do Norte, Natal, 2016. Disponível em: 〈https://goo.gl/ffgkiw〉. Acesso em: 04 maio 2017. 
OLIVEIRA, W. L. Boas práticas de manejo para o extrativismo sustentável do pequi. Brasília: Embrapa, 2010. Disponível em: <http://www.ispn.org.br/arquivos/Pequi2.pdf>. Acesso em: 04 maio 2017.

PESSOA, J. A colônia agrícola nacional de Goiás no aprendizado da itinerância. In: NEVES, D. P. (Org.). Processos de constituição e reprodução do campesinato no Brasil. São Paulo: Unesp; Brasília, DF: Núcleo de Estudos Agrários e Desenvolvimento Rural, 2009.

REZENDE, G. C. Ocupação agrícola e estrutura agrária no Cerrado: o papel do preço da terra, dos recursos naturais e da tecnologia. IPEA: texto para discussão. Rio de Janeiro, $\mathrm{n}^{\circ}$ 913, 2002, p. 6-23.

SACHS, I. Brasil, um século de transformações. São Paulo: Cia. das Letras, 2006.

SANO, S. M.; RIBEIRO, J. F.; BRITO, M. A. Baru: biologia e uso. Brasília: Embrapa, 2004. Disponível em: <http://www.cpac.embrapa.br/publicacoes/search_pbl/1?q=Baru>. Acesso em: 30 mar. 2017.

SHIKI, S. et al. Mercado de pagamento por serviços ambientais no Brasil no processo coevolucionário de desenvolvimento rural. In: MARQUES, F. C.; CONTERATO, M. A.; SCHNEIDER, S. (Orgs.). Construção de mercados e agricultura familiar: desafios para o desenvolvimento rural. Porto Alegre: Editora da UFRGS, 2016.

SHIKI, S. Sistema agroalimentar nos Cerrados brasileiros: caminhos para o caos? In: SHIKI, S.; SILVA, J. G.; ORTEGA, A. C. Agricultura, meio ambiente e sustentabilidade no Cerrado brasileiro. Uberlândia: UFU, 1997.

SILVA, D. M. da. Cadeia produtiva de pequi no estado de Goiás: análise do ambiente organizacional e institucional. 2011. 63 f. Monografia (Graduação) - Gestão do Agronegócio Universidade de Brasília (DF), 2011. Disponível em: 〈https://goo.gl/uuQTQA>. Acesso em: maio 2016.

SILVA, J. A. da et al. Coleta de sementes, produção de mudas e plantio de espécies frutíferas nativas dos cerrados: informações exploratórias. Planaltina: Embrapa, 1992. Disponível em: <http://www.cpac.embrapa.br/download/2489/t>. Acesso em: 02 maio 2017.

SILVA, L. L. O papel do Estado no processo de ocupação das áreas de Cerrado entre as décadas de 60 e 80. In: Caminhos de Geografia. Uberlândia, MG, v. 1, n. 2, p. 24-36, 2000.

SILVA, S. M. da C. e. Caracterização agronômica de variedades botânicas de Hancornia speciosa Gomes do Cerrado. 2013. 171 f. Tese (Doutorado em Agronomia)- Escola de Agronomia, Universidade Federal de Goiás, Goiânia, 2013. Disponível em: <https://goo.gl/HTGdKy>. Acesso em: 02 maio 2017.

SOUZA, O. R. de; NASSER, V. L.; SOARES, A. R. F. S. Contribuição da castanha do barú como fonte de renda para família extrativista do município de Orizona em Goiás. In: CONGRESSO BRASILEIRO DE GESTÃO AMBIENTAL. 4. 2013. Salvador. Anais... Salvador: Unijorge, 2013. Disponível em: <https://goo.gl/fh3iQH>. Acesso em: 02 maio 2017. 
VEIGA, J. E. da; EHLERS, E. Diversidade biológica e dinamismo econômico no meio rural. In: MAY, P. H. (Org.). Economia do meio ambiente: teoria e prática. 2. ed. Rio de Janeiro: Elsevier, 2010.

VIEIRA, R. F. et al. Frutas nativas da região Centro-Oeste do Brasil. Brasília: Embrapa, 2006. Disponível em: <https://goo.gl/moKAJ4>. Acesso em: 04 maio 2017.

ZYLBERSZTAIN, D.; NASSAR, A. M.; NEVES, M. F. Economia e gestão de negócios agroalimentares: indústria de alimentos, indústria de insumos, produção agropecuária e distribuição. São Paulo: Pioneira, 2000.

Artigo recebido em 31/03/2017. Aceito para publicação em 06/07/2017. 